suffered, and it is even possible that his well-deserved popularity would (as was manifestly expected) have done something to promote the return of his colleagues, had not the society, at a period too near the election for contradiction in the medical journals, issued a canvansing card containing the statement that "plumping was not permitted." The inaccuracy of this statement, and the quibbles by which it was presently defended, may be held to have so far dis. gusted a large number of voters as to prevent them from supporting any one of the trio thus offered to their notice, while there can be no doubt that many were deceived by it and were led to believe that they could not vote for Dr. Glover without voting also for the other candidates who were associated with him, and whose supporters fell short of his by 936 and 1520 respectively. On the next occasion I hope that Dr. Glover will stand alone, and I have no doubt that he will then return to his former position on the poll.

In the meanwhile, the most important outcome of the election is that the Council will now be able to proceed with the orderly discharge of its statutory duties, and that any chance of adding to these duties or of increasing the number of direct representatives may be looked upon as having passed out of the domain of practical politics.-I have the bonour to be, Sirs, your obedient servant,

Harley-street, W., Dec. 14th, 1896. R. BRUdeneld CARTER.

\section{COLOTOMY IN CHRONIC DYSENTERY.}

\section{To the Editors of THE LANCET.}

SIRs, - Some years ago, whilst house physician in one of the largest provincial hospitals, I had under my care a young man suffering from chronic dysentery. His daily evacuations numbered at least from fifteen to twenty and were of the usual character. In his case numerous drugs were resorted to, among them ipecacuanha, bismuth, quinine, red gum, naphthalin, \&c.; also various applications to the abdominal parietes, as heat, cold, and counter.irritants. Frequent rectal injections of various drugs were also tried. Notwithstanding all these endeavours to arrest or alleviate the chronic dysenteric evacuations the patient steadily became worse, with increasing weakness and emaciation. It then occurred to me that as it was an established fact that the lesions were generally confined to the large intestine, then the primary point of importance must be to give the large intestine as nearly as possible absolute rest. 'This I considered could only be done by performing a right inguinal colotomy. My views were laid before one of the honorary surgeons, who, however, considered the patient too weak to undergo such a procedure. As far as I can remember the patient lived a fortnight longer. At the ensuing necropsy I was most particularly struck with the fact that the lesions were absolutely confined to the large intestine, and felt convinced that had a right-sided colotomy been performed it would, at least, have given the patient a chance of recovery. May I therefore suggest that in all such cases as the one quoted above right-sided colotomy is imperatively called for. It not only gives complete rest to the large intestine, but by its means, if considered necessary or advisable, irrigation of the large bowel can be carried out with antiseptic lotions or even other applications adopted. I am, Sirs, yours faithfully,

Wrexham, Nov. 23rd, 1896. J. A. EYToN-JoNES,

** The method of treatment was discussed last year at the Clinical Society, ${ }^{1}$ one of the speakers saying that it had been suggested many years ago.-ED. L.

\section{DISTOMA PULMONALE.}

\section{To the Editors of THE LANCET.}

Sins, - The sixth volume of "Twentieth Century Practice" has just reached me. From the last page I learn that "a new parasite has recently been discovered in the lungs of cats, dogs, tigers, and man (Henry B. Ward, Mtdical News, March 2nd, 1895). It is called distona Westermanni and is supposed to be of Asiatic origin." The distase caused by this parasite is dismissed in less than twenty lines. Possibly the editor of "Twentieth Century Practice" intends to devote a special section to the diseases of warm climates, in which a fuller account of distomatosis pulmonum will be given. The space at present allotted to the disease seems quite inadequate. But for a work entitled "Twentieth Century Practice" to speak of this distoma as a new parasite when it has been well known for thrte or four years longer than the tubercle bacillus is absurd. The parasite is mentioned by von Jaksch. ${ }^{1}$ There is a short account of it by Manson under the heading "Distoma Ringeri vel Pulmonale" in the second cdition of "Quain's Dictionary of Medicine"; and under the name of "distoma Ringeri" it is mentioned on page 285 of the 1885 edition of the "Nomenclature of Diseases" of the Royal College of Physicians of London.

But the best account of the parasite and of the disease to which it gives rise is contained in a work, less widely known than those just mentioned, by Baelz, Professor of Medicine at the Imperial University of Tokyo, Japan. ${ }^{2}$ Baelz was the original discoverer of the parasite in 1878 , but he at first mistook the ova found in the sputum for greganinida. It was independently found and described in the following year by Ringer at Tamsui in Formosa. By both these observers and by Manson the importance of the parasite was clearly recognised as the true cause of the endemic hrmoptysis so widely p:evalent in Japan and Formosa and known also in Korea. To give an idea of the frequency of the disease in some districts of Japan I may mention that in Kumamoto a few years ago 39 per cent. of the schoolboys of the town were found to suffer from the disease. Baelz calls the parasite "distoma pulmonale"; Cobbold named it "distoma Ringeri." To re-christen it "distoma Westermanni" is undesirable. "Distoma pulmonale" is the best name; it raises no question as to priority of discovery, and by its affinity with the names "distoma hæmotobium" and "distoma hepaticum" it aids the memory and pleases an orderly mind. I am, Sirs, yours faithfully,

Nagasaki, Jaball, Oct. 26th, 1896. MAURICE EDEA PAUL.

\section{THE WATER-SUPPLY OF MADEIRA.}

\section{To the Editors of THE LANOET.}

SiRs,-I was only able to see a copy of TRE LANCET of Nov. '21st, received here by our last mail, containing a comment upon my letter published by me a week before (Nov. 14th). I think it only fair that you should know that at an adjourned meeting of all British residents held here "to consider the water question of Funchal and certain misstatements in the last consular report," a letter from our consul was read, in which he most strongly corrected his last report; and this letter was sent to the Foreign Office asking that it might be published in the Times. But owing to For eign Office regulations this was not obtainable, so we must wait for the next issue of a consular report. Meanwhile a wrong impression has been published abroad, which our letter, containing nothing but reliable facts and full details, was intended to rectify.

I am, Sirs, yours faithfully,

Madeira, Dec. 7th, 1896

FREDERICK J. Hicks, M.A., M.B. Oxon., \&c.

\section{VITAL STATISTICS OF THE CITY OF LONDON.}

To the Editors of THE LANCET.

SIRS--In THE LANCET of Dec. 12th, quoting from a report of the Medical Officer of Health for the City of London, you say (p. 1711): "The general death-rate of the City during 1895 was 18.3 per 1000 , as against a rate of 19.4 for the metropolis as a whole." In the "Annual Summary" of the RegistrarGeneral for 1895 it is stated that (Table H., p. xiv) after distribution of deaths to their proper sanitary areas there were 720 deaths accredited to "The City." Taking the population at 33,823 this gives a death-rate of 212 and not 18.3. As there is a difference of over 15 per cent. between these two 